\title{
The chromosome content and genotype of two wheat cell lines and of their somatic fusion product with oat
}

\author{
Fengning Xiang $\cdot$ Junfeng Wang $\cdot$ Chunhui Xu • \\ Guangmin Xia
}

Received: 22 September 2009/Accepted: 1 February 2010/Published online: 5 March 2010

(C) The Author(s) 2010. This article is published with open access at Springerlink.com

\begin{abstract}
Somatic hybridization seeks to genetically combine phylogenetically distant parents. An effective system has been established in bread wheat (Triticum aestivum L.) involving protoplasts from a non-totipotent cell line adapted to in vitro culture $\left(\mathrm{T}_{1}\right)$ in combination with totipotent protoplasts harvested from embryogenic calli $\left(\mathrm{T}_{2}\right)$. Here, we report the karyotype and genotype of $\mathrm{T}_{1}$ and $\mathrm{T}_{2}$. Line $\mathrm{T}_{1}$ carries nine A (A-genome of wheat), seven $B$ (B-genome of wheat) and eight $D$ (D-genome of wheat) genome chromosomes, while $\mathrm{T}_{2}$ cells have $12 \mathrm{~A}, 10$ $\mathrm{B}$ and $12 \mathrm{D}$ genome chromosomes. Rates of chromosome aberration in the B- and D-genomes were more than $25 \%$, higher than in the A-genome. DNA deletion rates were $55.6 \%$ in $\mathrm{T}_{1}$ and $19.4 \%$ in $\mathrm{T}_{2}$, and DNA variation rates were $8.3 \%$ in $\mathrm{T}_{1}$ and $13.9 \%$ in $\mathrm{T}_{2}$. Rate of DNA elimination was B- $>$ D- $>$ A-genome in both $\mathrm{T}_{1}$ and $\mathrm{T}_{2}$. The same set of cytological and genetic assays was applied to a derivative of the somatic fusion between protoplasts of $\mathrm{T}_{1}, \mathrm{~T}_{2}$ and oat (Avena sativa L.). The regenerant plants were near euploid with respect to their wheat complement. Six wheat chromosome arms-4AL, 3BS, 4BL, 3DS, 6DL and 7DL-carried small introgressed segments of oat chromatin. A genotypic analysis of the hybrid largely confirmed this cytologically-based diagnosis.
\end{abstract}

Electronic supplementary material The online version of this article (doi:10.1007/s00425-010-1113-1) contains supplementary material, which is available to authorized users.

F. Xiang · J. Wang · C. Xu · G. Xia ( $₫)$

The Key Laboratory of Plant Cell Engineering and Germplasm Innovation, Ministry of Education, School of Life Sciences, Shandong University, 27 Shandanan Road, Jinan 250100,

People's Republic of China

e-mail: xiagm@sdu.edu.cn
Keywords Chromosome content and genotype . Common wheat $\cdot$ Oat $\cdot$ Somatic hybrid

$\begin{array}{ll}\text { Abbreviations } \\ \mathrm{T} & \text { Triticum aestivum cv. Jinan } 177 \\ \mathrm{~T}_{1} & \text { Jinan } 177 \text { suspension cells } \\ \mathrm{T}_{2} & \text { Jinan } 177 \text { embryogenic calli } \\ \mathrm{SSR} & \text { Simple sequence repeats } \\ \mathrm{GISH} & \text { Genomic in situ hybridization } \\ \text { FISH } & \text { Fluorescence in situ hybridization }\end{array}$

\section{Introduction}

Numerous studies have been focused on analysis of somaclonal variation in vitro (Larkin et al. 1984; Lee and Phillips 1988; Pershina et al. 2003). The initial reports were concerned with determining changes in the number, structure, and morphology of the chromosomes, such as chromosome banding patterns (Larkin et al. 1984; Lee and Phillips 1988), and later studies examined variations in genomic DNA caused by mutations, the loss and rearrangement of genes, gene silencing and transposons or reverse transposons in subculture (Shaked et al. 2001; Polanco and Ruiz 2002; James and Reiner 2007). However, little was known about the content and genotype of cultured cells of allohexaploid wheat (Triticum aestivum L.) that had been grown for different periods of time.

Wheat (T. aestivum L., $2 n=42$ ) is an important cereal. The genetic variability for some important traits, such as high quality, diseases and stress resistance, is limited in the cultivated wheat germplasm. Related or distant species of wheat are an important reservoir of useful genes (Liu et al. 
2005). There is thus an urgent need to broaden the wheat gene pool by introgressing genes for such traits from diverse cereal species. This kind of alien introgression line created can increase the genetic variation in wheat species. However, the sexual route with low crossability in achieving this limited the transfer of such genes (Wang et al. 2004; Liu et al. 2005). Somatic hybridization provides the possibility of overcoming sexual incompatibility of wheat with remote cereals (Xia et al. 2003). This technique has been used with some success as a means of introgressing genes from related grass and cereal species (Xia et al. 2003; Wang et al. 2005; Zhou and Xia 2005). However, when the donor species was only distantly related to wheat, fusions often failed to progress beyond undifferentiated calli or albino plants (Xiang et al. 1999; Li et al. 2001; Yue et al. 2001). In an attempt to overcome the difficulty of regenerating hybrids between distantly related species, a three-parent fusion system has been elaborated (Xiang et al. 2003a, 2004; Xu et al. 2003), based on two complementary wheat cell lines $\mathrm{T}_{1}$ and $\mathrm{T}_{2}$. The former is a non-totipotent cell line growing in long-term cell suspension, and the latter are totipotent cells taken from embryogenic calli (Xiang et al. 2003b). The third "parent" is an exotic donor species, the protoplasts of which are irradiated before fusion. Using this system, Xiang et al. (2003a) were able to regenerate a set of putative wheat/oat (Avena sativa L.) somatic hybrids and employed a combination of cytological and genetic assays to demonstrate the presence of a variable number of wheat/oat recombinant chromosomes. However, the contents and genotypes of the two wheat cell lines and their somatic fusion products with oat were unknown. This was critical for understanding the mechanism of the regeneration of hybrid plants.

In this work, our goal was to investigate the chromosome elimination and variation of $\mathrm{T}_{1}$ and $\mathrm{T}_{2}$, as well as the relationship between the genetic complementation of $\mathrm{T}_{1}$, $\mathrm{T}_{2}$, oat and somatic hybrid plant regeneration.

\section{Materials and methods}

Plant materials

Wheat protoplasts derived from two types of cell lines $\mathrm{T}_{1}$ and $\mathrm{T}_{2}$ of $T$. aestivum $\mathrm{L}$. cv. Jinan 177 , and oat protoplasts came from embryogenic calli A. sativa L. cv. Mapur. The $\mathrm{T}_{1}$ were harvested from a non-regenerable long-term ( $>10$ years) cell suspension, and the $T_{2}$ from 2-year-old embryogenic calli with regeneration frequency of $75 \%$ (number of calli which can differentiate to plants/number of calli analysed, \%) (Xiang et al. 2003a). The oat cell line was 1.5-year-old embryogenic calli (Xiang et al. 2003a).
The $\mathrm{T}_{1}$ and $\mathrm{T}_{2}$ lines were subcultured on $\mathrm{MB}$ liquid and solid media (Xia and Chen 1996) with $2.0 \mathrm{mg} / \mathrm{L} \mathrm{2,4-}$ dichlorophenoxyacetic acid (2,4-D). Protoplasts were isolated from $\mathrm{T}_{1}$ suspension after 3 days of subculture, $\mathrm{T}_{2}$ and oat embryogenic calli were isolated 7 days after subculture according to the method of Xia and Chen (1996). After washing in $0.6 \mathrm{M}$ mannitol and $5 \mathrm{mM} \mathrm{CaCl}_{2}$, oat protoplasts were transferred onto $3.5 \mathrm{~cm}$ Petri dishes in a thin layer and irradiated with UV light at an intensity of $300 \mu \mathrm{W} / \mathrm{cm}^{2}$ for $1 \mathrm{~min}$ before they were fused with $T_{1}$ and $\mathrm{T}_{2}$ (Xiang et al. 2003a). $\mathrm{T}_{1}$ and $\mathrm{T}_{2}$ protoplasts were combined at the ratio of $1: 1$ and mixed in equal volumes with UV-treated protoplasts of oat. The fusion was carried out according to the improved PEG method (Xia and Chen 1996). When the fusion clones grew to small cell lines of $1.5-2.0 \mathrm{~mm}$ in diameter, they were transferred to the MB medium with $1 \mathrm{mg} / \mathrm{L} \mathrm{2,4-D}$ for proliferation. After subculture for 1-2 months, proliferating calli from the cell lines were moved to the MB medium containing $0.5 \mathrm{mg} / \mathrm{L}$ IAA and $0.5 \mathrm{mg} / \mathrm{L}$ zeatin for regeneration. Regenerated plantlets were transferred to seedling-strengthening MB medium containing 1-2 mg/L multi-effect triazal (MET) and $0.5 \mathrm{mg} / \mathrm{L}$ NAA for strengthening and rooting. All the regenerated plants from four hybrid clones resembled wheat, but only plants of clone no. 94-1 can grow into soil, and then tassel normally (Xiang et al. 2003a). In this experiment, a lager number of roots from hybrid plants of clone no. 94-1 in different growth stages were analysed. Accessions of Triticum urartu Thum, Aegilops speltoides Tausch and Aegilops tauschii (Cross.) Schmal were kindly provided by the Quality and Resource Institute of the Agriculture Science Academy of China.

Karyotype analysis and in situ hybridization

Chromosome spreads were obtained from $T_{1}$ and $T_{2}$ cells and from the root tips of the regenerants and germinating seedlings, as described by Xiang et al. (2003b). Karyotypes of cv. Jinan 177 were derived from a sample of ten mitotic metaphase cell spreads. Karyotype classification followed the method of Sears (1969) and was based on the data for Chinese Spring wheat from Gill (1987). The parameters of the karyotypes were based on ten metaphase cell spreads. The arm ratios and the relative distances of the chromosomes from the hybrid cells selected were analysed. For in situ hybridization (ISH) purposes, genomic DNA of cv. Jinan 177, oat, T. urartu, Ae. tauschii, Ae. speltoides and the hybrid regenerants was isolated following Doyle and Doyle (1990). The pSc119.2 and pAs1 plasmids contain, respectively, $\mathrm{B}$ and $\mathrm{D}$ genome-specific repetitive sequences (Mukai et al. (1993). These were labelled for use as fluorescence ISH (FISH) probes with digoxigenin-11-dUTP, using a nick translation kit, according to the manufacturer's 
instructions (Boehringer Mannheim, Germany), as described elsewhere (Wang et al. 2005). Total oat genomic DNA was labelled in the same way to generate a genomic ISH (GISH) probe. The GISH and FISH methodology followed Wang et al. (2005), the former using a ratio of 1:50 labelled oat genomic DNA to unlabelled wheat genomic DNA, and the latter 1:50 labelled pSc119.2 to unlabelled genomic ( $T$. urartu + Ae. tauschii) DNA, or 1:50 pAs1 to unlabelled genomic (T. urartu + Ae. speltoides) DNA. In sequential GISH and FISH experiments (pAs1/pSc119.2 and GISH/ $\mathrm{pAs} 1 / \mathrm{pSc} 119.2$ ), the initial signal was rinsed before rehybridization with the subsequent probe.

\section{Microsatellite (SSR) analysis}

DNA extracted from $T_{1}$ cells, $T_{2}$ calli and leaf of somatic hybrids and parental lines (Doyle and Doyle 1990) was used as template for the analysis of allelic constitution at 101 SSR loci, following Röder et al. (1998). The marker set covered the centromeric and subtelocentric regions of all the chromosomes present in $\mathrm{T}_{1}$ and $\mathrm{T}_{2}$, and the locations selected based on the previous GISH, FISH and karyotype analysis of hybrid. The relative distance (\%; the distance from the centromere to SSR locus checked/the length of the arm involved $\times 100 \%$ ) was measured according to the genetical map of Röder et al. (1998).

\section{Results}

The chromosome content of $\mathrm{T}_{1}$ and $\mathrm{T}_{2}$ and cv. Jinan 177

Of the $138 \mathrm{~T}_{1}$ cells analysed, $119(86.2 \%)$ contained $22-25$ chromosomes (Fig. 1a), while 104/124 (83.9\%) of the $\mathrm{T}_{2}$ cells had 34-38 chromosomes (Fig. 1b). Some $\mathrm{T}_{1}$ and $\mathrm{T}_{2}$ cells included telocentric chromosomes, acrocentric chromosomes and dicentric chromosomes (see Suppl. Table 1, Fig. 1a, b). One or two chromosome fragments were present in $\sim 87 \%$ of both the $\mathrm{T}_{1}$ and $\mathrm{T}_{2}$ cells. The karyotype of cv. Jinan 177 conformed to that of standard bread wheat (Gill 1987; Suppl. Table 2, Fig. 1c).

The genome content of $T_{1}$ and $T_{2}$ cells

FISH preparations based on hybridization with $\mathrm{pSc} 119.2$ and pAs1 succeeded in defining the $\mathrm{B}$ and $\mathrm{D}$ genome content of $\mathrm{T}_{1}$ and $\mathrm{T}_{2}$. From a sample of $136 \mathrm{~T}_{1}$ cells, 82 $(\sim 60 \%)$ contained seven B genome, and 83 ( $\sim 61 \%)$ contained eight $\mathrm{D}$ genome chromosomes (Table 1, Fig. 2a, b); similarly, of the $95 \mathrm{~T}_{2}$ cells analysed, $\sim 60 \%$ had ten $\mathrm{B}$ and $\sim 54 \% 12 \mathrm{D}$ genome chromosomes (Table 1, Fig. 2c, d). The range in the number of $\mathrm{B}$ and $\mathrm{D}$ genome a

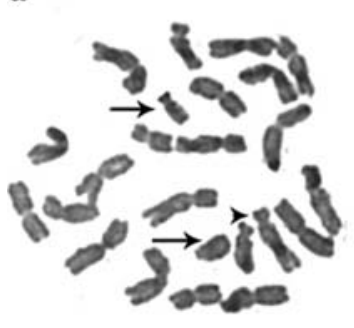

c

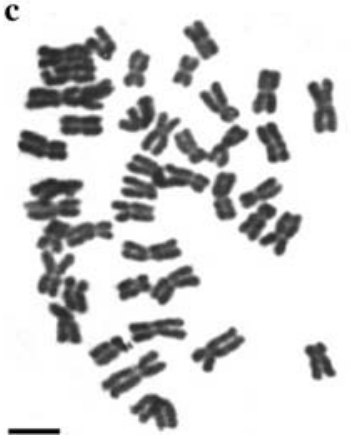

b

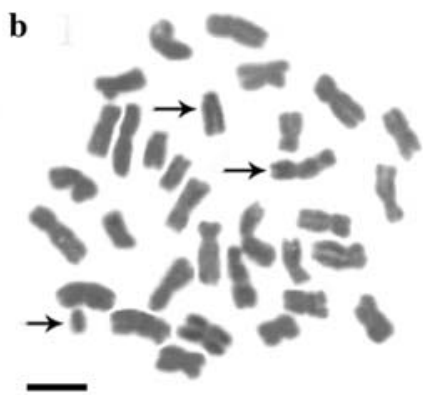

$\begin{array}{lllllll}1 & 2 & 3 & 4 & 5 & 6 & 7\end{array}$ A

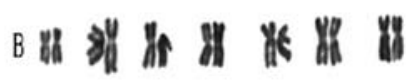

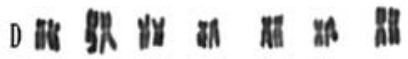

Fig. 1 Mitotic metaphase spreads of $T_{1}(\mathbf{a}), T_{2}(\mathbf{b})$, cv. Jinan 177 (c) and the karyotype of cv. Jinan 177 (d). Telocentric and subtelocentric chromosomes indicated by an arrow, dicentric chromosomes by an arrowhead

chromosomes in $T_{1}$ was, respectively, 6-8 and 7-9, and in $\mathrm{T}_{2}, 9-11$ and 10-12. Chromosomes 2B, 3B, 7B, 3D and 6D were present in most $T_{1}$ and $T_{2}$ cells, but $4 B, 5 B$ and $4 D$ were rare. Chromosome abnormalities were present in, respectively, 27 and $39 \%$ of the $\mathrm{T}_{1} \mathrm{~B}$ and $\mathrm{D}$ genome chromosomes and 31 and $36 \%$ of $\mathrm{T}_{2}$ chromosomes (Table 2). Therefore, many eliminations and rearrangements including duplication of B- and D-genome chromosomes in $T_{1}$ and $T_{2}$ presented in the calli subculture. Chromosome arm ratios and relative lengths were used to infer the A genome content of $\mathrm{T}_{1}$ and $\mathrm{T}_{2}$ cells. Comparing the statistics of karyotype data of $\mathrm{T}_{1}, \mathrm{~T}_{2}$ with $\mathrm{cv}$. Jinan 177, it was revealed that A genome chromosomes of $T_{1}$ and $T_{2}$ were distributed mainly in $4 \mathrm{~A}$ and $5 \mathrm{~A}$, whereas $3 \mathrm{~A}$ was the lowest. About $61 \%$ of $\mathrm{T}_{1}$ cells contained nine $\mathrm{A}$ genome chromosomes, while $\sim 57 \%$ of the $\mathrm{T}_{2}$ cells contained 12 (Table 1, Fig. 2a, b). The range in A genome chromosome number in $T_{1}$ was $7-11$, and in $T_{2} 11-15$. Non-standard $A$ genome chromosomes were present in $22 \%$ of $\mathrm{T}_{1}$ and $16 \%$ of $\mathrm{T}_{2}$ cells (Tables 1,2 ).

Distinguishing between DNA deletion and modification in $\mathrm{T}_{1}$ and $\mathrm{T}_{2}$

Simple sequence repeats genotyping was employed to distinguish between DNA deletion and modification in $\mathrm{T}_{1}$ and $\mathrm{T}_{2}$ as a result of cell culture. Of the 58 loci assayed, 36 exposed genetic polymorphism between $T_{1}$ and $T_{2}$ and $T$ 
Table 1 Frequency of pSc119.2 and pAs1 hybridization signals in $\mathrm{T}_{1}$ and $\mathrm{T}_{2}$ cell lines

\begin{tabular}{|c|c|c|c|c|c|c|c|c|c|c|}
\hline \multirow{2}{*}{$\begin{array}{l}\text { DNA } \\
\text { probe }\end{array}$} & \multirow[t]{2}{*}{ Material } & \multirow{2}{*}{$\begin{array}{l}\text { Main } \\
\text { chromosome } \\
\text { no. }\end{array}$} & \multirow{2}{*}{$\begin{array}{l}\text { Cell no. } \\
\text { observed }\end{array}$} & \multicolumn{7}{|c|}{ Signal number and frequency $(\%)$} \\
\hline & & & & $6(\%)$ & $7(\%)$ & $8(\%)$ & $9(\%)$ & $10(\%)$ & $11(\%)$ & $12(\%)$ \\
\hline \multirow[t]{6}{*}{ pAs1 } & $\mathrm{T}_{1}$ & 23 & 45 & & $7(15.5)$ & $29(64.4)$ & $9(20.1)$ & & & \\
\hline & & 24 & 58 & & $11(19.0)$ & $36(62.0)$ & $11(19.0)$ & & & \\
\hline & & 25 & 33 & & $6(18.2)$ & $19(57.6)$ & $7(21.2)$ & & & \\
\hline & $\mathrm{T}_{2}$ & 33 & 38 & & & & & $8(21.1)$ & $10(26.3)$ & $20(52.6)$ \\
\hline & & 34 & 25 & & & & & $4(16.0)$ & $7(28.0)$ & $14(56.0)$ \\
\hline & & 35 & 32 & & & & & $6(18.2)$ & $9(28.1)$ & $17(53.1)$ \\
\hline \multirow[t]{6}{*}{ pSc119.2 } & $\mathrm{T}_{1}$ & 23 & 44 & $14(31.8)$ & $25(56.8)$ & $5(11.4)$ & & & & \\
\hline & & 24 & 48 & $14(29.2)$ & $30(62.5)$ & $4(8.3)$ & & & & \\
\hline & & 25 & 31 & $7(22.6)$ & $19(61.3)$ & $5(16.1)$ & & & & \\
\hline & $\mathrm{T}_{2}$ & 33 & 19 & & & & $5(26.4)$ & $11(57.9)$ & $3(15.7)$ & \\
\hline & & 34 & 23 & & & & $5(21.7)$ & $14(60.9)$ & 4 (17.4) & \\
\hline & & 35 & 15 & & & & 4 (26.7) & $9(60.0)$ & $2(13.3)$ & \\
\hline
\end{tabular}

Fig. 2 FISH profile of the mitotic metaphase

chromosomes. $\mathbf{a}$ and $\mathbf{b} \mathrm{B}$ and $\mathrm{D}$ genome chromosomes of $\mathrm{T}_{1}$ identified by their pSc119.2 and pAsI patterns. $\mathbf{c}$ and $\mathbf{d} \mathrm{B}$ and $\mathrm{D}$ genome chromosomes of $\mathrm{T}_{2}$ identified by their $\mathrm{pSc} 119.2$ and pAsI patterns. Scale bars $10 \mu \mathrm{m}$
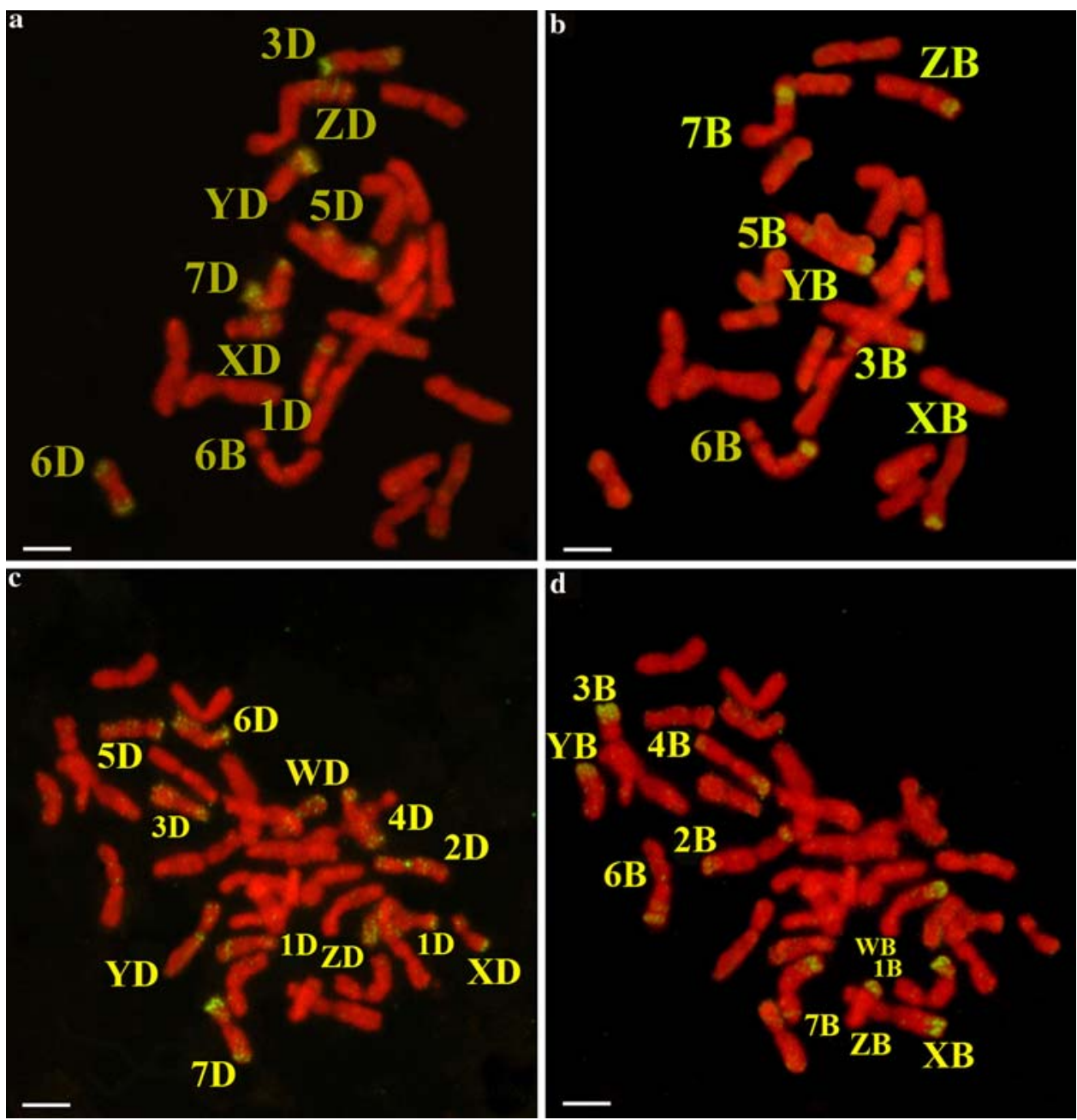

(cv. Jinan 177), and the remainder were non-informative (Table 3, Fig. 3). Of the 36 informative markers, 13 showed same patterns among $\mathrm{T}, \mathrm{T}_{1}$ and $\mathrm{T}_{2}, 15$ between $\mathrm{T}_{1}$ and cv. Jinan 177 and 25 between $\mathrm{T}_{2}$ and cv. Jinan 177 (Table 3). The rates of DNA deletion were 55.6\% (20/36) in $\mathrm{T}_{1}$, such as in Xgwm160 and Xgwm428 (Fig. 3), and 
Table 2 Chromosome constitution of the $\mathrm{T}_{1}$ and $\mathrm{T}_{2}$ lines

\begin{tabular}{|c|c|c|c|c|c|c|c|c|}
\hline $\begin{array}{l}\text { A-genome } \\
\text { chromosome }\end{array}$ & $\begin{array}{l}\mathrm{T}_{1} \\
\text { No. of } \\
\text { chromosome } \\
(\%)\end{array}$ & $\begin{array}{l}\mathrm{T}_{2} \\
\text { No. of } \\
\text { chromosome } \\
(\%)\end{array}$ & $\begin{array}{l}\text { B-genome } \\
\text { chromosome }\end{array}$ & $\begin{array}{l}\mathrm{T}_{1} \\
\text { No. of } \\
\text { chromosome } \\
(\%)\end{array}$ & $\begin{array}{l}\mathrm{T}_{2} \\
\text { No. of } \\
\text { chromosome } \\
(\%)\end{array}$ & $\begin{array}{l}\text { D-genome } \\
\text { chromosome }\end{array}$ & $\begin{array}{l}\mathrm{T}_{1} \\
\text { No. of } \\
\text { chromosome } \\
(\%)\end{array}$ & $\begin{array}{l}\mathrm{T}_{2} \\
\text { No. of } \\
\text { chromosome } \\
(\%)\end{array}$ \\
\hline $1 \mathrm{~A}$ & 8 (8.89) & $5(9.09)$ & $1 \mathrm{~B}$ & $10(8.93)$ & $7(8.33)$ & $1 \mathrm{D}$ & $14(11.86)$ & $12(6.78)$ \\
\hline $2 \mathrm{~A}$ & $9(10.00)$ & $7(12.73)$ & $2 \mathrm{~B}$ & $16(14.29)$ & $8(9.52)$ & $2 \mathrm{D}$ & 9 (7.63) & $26(14.69)$ \\
\hline $3 \mathrm{~A}$ & $4(4.44)$ & $2(3.64)$ & $3 B$ & $16(14.29)$ & $16(19.05)$ & $3 \mathrm{D}$ & 14 (11.86) & 21 (11.86) \\
\hline $4 \mathrm{~A}$ & $21(23.33)$ & $9(16.36)$ & $4 \mathrm{~B}$ & $4(3.57)$ & $4(4.76)$ & $4 \mathrm{D}$ & $5(4.24)$ & $6(3.39)$ \\
\hline $5 \mathrm{~A}$ & $13(14.44)$ & $12(21.82)$ & $5 \mathrm{~B}$ & $8(7.14)$ & $3(3.57)$ & $5 \mathrm{D}$ & $7(5.94)$ & $15(8.47)$ \\
\hline $6 \mathrm{~A}$ & 7 (7.78) & $5(9.09)$ & $6 \mathrm{~B}$ & $12(10.71)$ & $8(9.52)$ & $6 \mathrm{D}$ & $19(16.10)$ & $18(10.17)$ \\
\hline 7A & 8 (8.89) & $6(10.91)$ & $7 \mathrm{~B}$ & $16(14.29)$ & $12(14.29)$ & $7 \mathrm{D}$ & 4 (3.39) & $16(9.05)$ \\
\hline XA & $20(22.22)$ & $9(16.36)$ & $\mathrm{XB}$ & $30(26.79)$ & $26(30.95)$ & $\mathrm{XD}$ & $46(38.98)$ & $63(35.59)$ \\
\hline Total & $90(100)$ & $55(100)$ & Total & $112(100)$ & 84 (100) & Total & $118(100)$ & 177 (100) \\
\hline
\end{tabular}

$19.4 \%(7 / 36)$ in $\mathrm{T}_{2}$, such as in Xgwm335 (Fig. 3) and Xgwm273, and $16.7 \%(6 / 36)$ in both $\mathrm{T}_{1}$ and $\mathrm{T}_{2}$ (Table 3 ). This indicated that the rate of DNA deletion of $T_{1}$ was higher than that of $\mathrm{T}_{2}$. The ratio of DNA modification was $8.3 \%$ (3/36) in $\mathrm{T}_{1}$ with examples such as Xgwm389 (Fig. 3) and Xgwm160 (Fig. 3). In $\mathrm{T}_{2}$ the ratio of DNA modification was $13.9 \% \quad(5 / 36)$, with examples of Xgwm389, Xgwm335 and Xgwm428 (Table 3, Fig. 3). B-genomic DNA was eliminated at a faster rate than D-genomic DNA, which was deleted faster than A-genomic DNA in $T_{1}$ and $T_{2}$. Anyway, the rate of DNA deletion was greater in $T_{1}$ than in $T_{2}$, while the rate of DNA modification was greater in $T_{2}$ than in $T_{1}$ (Table 3). Therefore, there were many instances of DNA variation at different positions in $T_{1}$ and $T_{2}$, and within the calli of subcultures of wheat.

\section{Introgression of oat chromatin into wheat}

About $71 \%$ of the cells of the hybrid regenerants contained 46-48 chromosomes (mean 47.2), with $\sim 58 \%$ containing oat chromosome introgression segments distributed on six wheat chromosomes. Based on sequential ISH experiments, it was possible to identify $12-16$ of the B genome and 11-13 of the D genome chromosomes (Table 4, Fig. 4a, b). By comparing their karyotype with that of $\mathrm{cv}$. Jinan 177, 17 A genome chromosomes and three chromosomal abnormalities were detected (Table 4). Almost the whole wheat genome was represented in the hybrid nuclei, along with duplicated, deleted or re-arranged chromosomes. The GISH/FISH analysis identified the presence of oat chromatin on chromosomes $3 \mathrm{~B}$ and $4 \mathrm{~B}$ (Fig. 4a, c), and 3D, 6D and 7D (Fig. 4b, c). A further introgression site was identified indirectly on chromosome 4A (Fig. 4c). The arm locations of the six introgression sites were 4AL, 3BS, 4BL, 3DS, 6DL and 7DL (Table 5, Fig. 4). An analysis of the arm ratios of the introgressed chromosomes, and the relative distances between the centromere and the introgression break point are given in Table 5.

Of the 58 SSR loci used to genotype the hybrid regenerants, 32 were amplified in all of the samples. Of the 32 informative markers, only 14 (43.8\%) identified differences between hybrid plants and their parents. The alleles from both parents were present at nine of above 14 loci, only the oat allele was amplified at two loci, while at the remaining three loci, the alleles were biparental and novel (Table 6). The relative distance $(\%)$ between the centromeres and the SSR loci were measured. SSR bands were located on 4AL, 3BS, 4BL, 3DS, 6DL and 7DL chromosome arms, and the relative distances $(\%)$ of fragments ranged from 3.10 to $76.36 \%$ (Table 6), in agreement with the results of sequential GISH and FISH (Table 5). Oat alleles were also amplified by primers targeting SSR loci on chromosome arms 3AS, 3AL, 6AL and 7AL, none of which were identified by GISH as sites of introgression (Table 6). This observation is suggestive of the occurrence of many submicroscopic introgression events.

\section{Discussion}

By using the $\mathrm{pSc} 119.2$ with high repetitive sequences of B-genome from rye (Secale cereale L.), and pAs1 with insertion of repetitive sequences of D-genome from $A e$. tauschii for two-colour FISH, Mukai et al. (1993) established the ideogram of B- and D-genomes and a pair of 4A chromosomes of Chinese Spring wheat. Using N-, C-banding, GISH, FISH and SSR markers in combination with karyotypes data, heterogeneric chromatin in many wheat hybrids were localized into the wheat chromosomes (Jiang et al. 1993; Nagy et al. 2002; Malysheva et al. 2003; Silkova et al. 2006). Our previous result had also confirmed that FISH analysis with pSc119.2 and pAs1, in combination with karyotype data and GISH, could differentiate all 
Table 3 SSR profiles of cv. Jinan 177 and $T_{1}$ and $T_{2}$ cell lines

\begin{tabular}{|c|c|c|c|c|c|}
\hline \multirow[t]{2}{*}{ Primer } & \multirow[t]{2}{*}{ Location } & \multicolumn{4}{|c|}{ The amplification result of wheat and its calli } \\
\hline & & Jinan 177 & $\mathrm{~T}_{1}$ & $\mathrm{~T}_{2}$ & $\begin{array}{l}\text { Deletion and modification } \\
\text { of genomic DNA } \\
\text { in } \mathrm{T}_{1} \text { and } \mathrm{T}_{2}\end{array}$ \\
\hline Xgwm359 & $1 \mathrm{AS}$ & $\mathrm{T}$ & $\mathrm{T}$ & $\mathrm{T}$ & \\
\hline Xgwm47 & $2 \mathrm{AL}$ & $\mathrm{T}$ & $\mathrm{T}$ & $\mathrm{T}$ & \\
\hline Xgwm674 & $3 \mathrm{AL}$ & $a+b$ & 0 & $a+b$ & $\mathrm{D}$ in $\mathrm{T}_{1}$ \\
\hline Xgwm369 & $3 \mathrm{AS}$ & $a+b$ & a & $a+b$ & $\mathrm{D}$ in $\mathrm{T}_{1}$ \\
\hline Xwmc258 & $4 \mathrm{AL}$ & $a+b$ & 0 & 0 & $\mathrm{D}$ in $\mathrm{T}_{1}$ and $\mathrm{T}_{2}$ \\
\hline Xwmc262 & $4 \mathrm{AL}$ & $a+b$ & 0 & $a+b$ & $\mathrm{D}$ in $\mathrm{T}_{1}$ \\
\hline Xgwm160 & $4 \mathrm{AL}$ & $a+b$ & $\mathrm{a}+\mathrm{N}$ & $a+b$ & $\mathrm{D}$ in $\mathrm{T}_{1}, \mathrm{M}$ in $\mathrm{T}_{1}$ \\
\hline Xgwm637 & $4 \mathrm{AL}$ & $\mathrm{T}$ & $\mathrm{T}$ & $\mathrm{T}$ & \\
\hline Xgwm494 & $6 \mathrm{AL}$ & $\mathrm{T}$ & $\mathrm{T}$ & $\mathrm{T}$ & \\
\hline Xgwm63 & 7AL & $a+b$ & 0 & $a+b$ & $\mathrm{D}$ in $\mathrm{T}_{1}$ \\
\hline Xgwm140 & $1 \mathrm{BL}$ & $\mathrm{T}$ & $\mathrm{T}$ & $\mathrm{T}$ & \\
\hline Xgwm273 & 1BS & $a+b+c$ & a & $\mathrm{N}$ & $\mathrm{D}$ in $\mathrm{T}_{1}$ and $\mathrm{T}_{2}, \mathrm{M}$ in $\mathrm{T}_{2}$ \\
\hline Xgwm297 & $3 \mathrm{BL}$ & $\mathrm{T}$ & $\mathrm{T}$ & $\mathrm{T}$ & \\
\hline Xgwm247 & $3 \mathrm{BL}$ & $a+b$ & 0 & $a+b$ & $\mathrm{D}$ in $\mathrm{T}_{1}$ \\
\hline Xgwm547 & 3BS & $\mathrm{T}$ & $\mathrm{T}$ & $\mathrm{T}$ & \\
\hline Xpsp3030 & 3BS & $a+b+c$ & $a+b$ & $a+b$ & $\mathrm{D}$ in $\mathrm{T}_{1}$ and $\mathrm{T}_{2}$ \\
\hline Xgwm285 & 3BS & $\mathrm{T}$ & $\mathrm{T}$ & $\mathrm{T}$ & \\
\hline Xgwm231 & $3 \mathrm{BS}$ & $a+b+c+d$ & $a+b+c$ & $a+b$ & $\mathrm{D}$ in $\mathrm{T}_{1}$ and $\mathrm{T}_{2}$ \\
\hline Xgwm389 & $3 \mathrm{BS}$ & a & $\mathrm{a}+\mathrm{N}$ & $a+N$ & $M$ in $T_{1}$ and $T_{2}$ \\
\hline Xgwm77 & 3BS & $\mathrm{T}$ & $\mathrm{T}$ & $\mathrm{T}$ & \\
\hline Xwmc69 & 3BS & $a+b$ & 0 & $a+b$ & $\mathrm{D}$ in $\mathrm{T}_{1}$ \\
\hline Xgwm107 & $4 \mathrm{BL}$ & $a+b+c+d+e$ & $a+b+c$ & $a+b+c+d+e$ & $\mathrm{D}$ in $\mathrm{T}_{1}$ \\
\hline Xgwm165 & $4 \mathrm{BL}$ & $a+b$ & 0 & $a+b$ & $\mathrm{D}$ in $\mathrm{T}_{1}$ \\
\hline Xgwm368 & 4BS & $\mathrm{T}$ & $\mathrm{T}$ & $\mathrm{T}$ & \\
\hline Xgwm335 & $5 \mathrm{BL}$ & a & a & $\mathrm{N}$ & $\mathrm{D}$ in $\mathrm{T}_{2}, \mathrm{M}$ in $\mathrm{T}_{2}$ \\
\hline Xgwm219 & $6 \mathrm{BL}$ & $\mathrm{T}$ & $\mathrm{T}$ & $\mathrm{T}$ & \\
\hline Xgwm537 & 7BS & $a+b$ & 0 & $a+b$ & $\mathrm{D}$ in $\mathrm{T}_{1}$ \\
\hline Xgwm157 & $1 \mathrm{DL}$ & $\mathrm{T}$ & $\mathrm{T}$ & $\mathrm{T}$ & \\
\hline Xgwm337 & $1 \mathrm{DS}$ & $a+b+c$ & $a+b$ & $a+b+c$ & $\mathrm{D}$ in $\mathrm{T}_{1}$ \\
\hline Xgwm314 & $3 \mathrm{DL}$ & $\mathrm{T}$ & $\mathrm{T}$ & $\mathrm{T}$ & \\
\hline Xgwm456 & 3DS & $a+b$ & $a+b$ & $\mathrm{a}+\mathrm{b}+\mathrm{N}+\mathrm{N}$ & $M$ in $T_{2}$ \\
\hline Xgdm98 & $6 \mathrm{DL}$ & $a+b$ & 0 & $a+b$ & $\mathrm{D}$ in $\mathrm{T}_{1}$ \\
\hline Xgwm428 & 7DL & $a+b$ & 0 & $a+b+N$ & $\mathrm{D}$ in $\mathrm{T}_{1}, \mathrm{M}$ in $\mathrm{T}_{2}$ \\
\hline $\mathrm{Xgdm} 46$ & $7 \mathrm{DL}$ & $a+b$ & $\mathrm{~b}$ & $\mathrm{a}$ & $\mathrm{D}$ in $\mathrm{T}_{1}$ and $\mathrm{T}_{2}$ \\
\hline Xpsp3079 & 7DL & $a+b+c+d$ & $a+b+c+N$ & $a+b+c$ & $\mathrm{D}$ in $\mathrm{T}_{1}$ and $\mathrm{T}_{2}, \mathrm{M}$ in $\mathrm{T}_{1}$ \\
\hline Xgwm437 & 7DL & $a+b$ & 0 & $a+b$ & $\mathrm{D}$ in $\mathrm{T}_{1}$ \\
\hline \multirow[t]{2}{*}{ Rate of D (\%) } & $\mathrm{T}_{1}$ & 55.6 & Rate of M (\%) & $\mathrm{T}_{1}$ & 8.3 \\
\hline & $\mathrm{T}_{2}$ & 19.4 & & $\mathrm{~T}_{2}$ & 13.9 \\
\hline
\end{tabular}

of the A-, B- and D-genome chromosomes of the cultivar wheat Jinan 177 and localize small donor chromosomes in somatic hybrid of Jinan 177 with Agropyron elongatum (Wang et al. 2005). Here, we have extended this analysis to the three-cell fusion system (Xiang et al. 2003a), which has uncovered chromosome content and genotype of two wheat cell lines and of their somatic hybrid plant with oat.
Chromosome loss and variation in the $T_{1}$ and $T_{2}$ cell lines

Variation in chromosome number and the formation of chromosomal aberrations are common in cells cultured in vitro over many generations (Larkin et al. 1984; Song et al. 2000). Here we have shown that the $T_{1}$ cell line has lost 


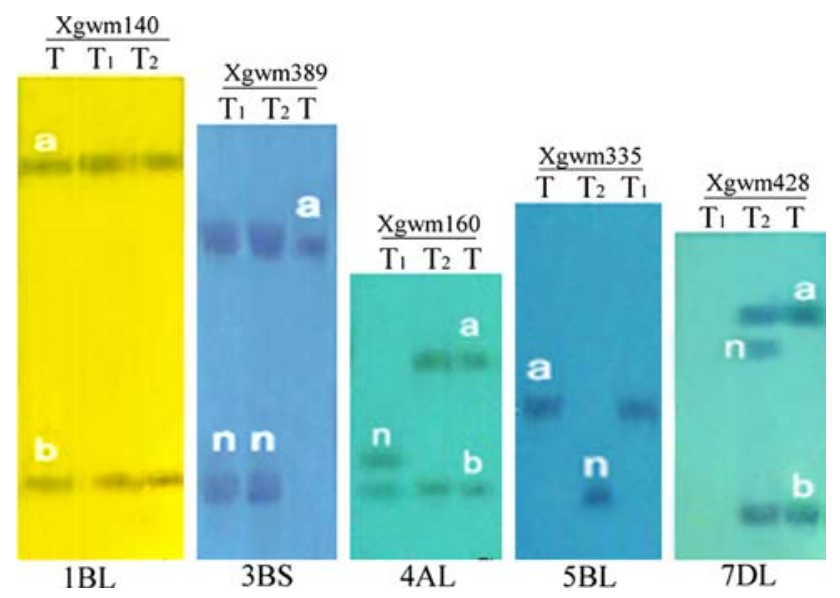

Fig. 3 SSR profiles of cv. Jinan $177(T)$ and cell lines $T_{1}$ and $T_{2}$, based on primers directed to loci on wheat chromosome arms 1BL, 3BS, 4AL, 5BL and 7DL. a, b: cv. Jinan 177 allele; $n$ novel allele

about 18 , while $\mathrm{T}_{2}$ has lost only about eight chromosomes (Table 1, Fig. 2), as would be expected given that $T_{1}$ has been in culture for a much longer period than $T_{2}$. The evidence is that particular chromosomes tend to be more highly prone to loss, while others are lost rather rarely, as has been noted in other studies (Lee and Phillips 1988;
Doğramaci-Altuntepe et al. 2001). The former group includes chromosomes 4A, 5A, 3B, 7B, 3D, 6D, and the latter chromosomes 3A, 6A, 4B, 5B and 4D (Table 2). As for the chromosomal abnormalities of $T_{1}$ and $T_{2}$, the frequencies in D-, B-groups were higher than that of the A-group, with the order of D- $>$ B- $>$ A-group in both $\mathrm{T}_{1}$ and $\mathrm{T}_{2}$ (Table 2).

Hybrid chromosome number and regeneration ability

Previous studies have indicated that the totipotency of a hybrid cell line was dependent on the number of chromosomes present, so those having a chromosome number close to the bread wheat somatic number of 42 tended to be more fit than those which were either hypo- or hyper-ploid (Xia et al. 1996; Xiang et al. 2003a, 2004). The majority of the regenerants from the wheat/oat fusion had a chromosome number in the range 46-48, far less than the sum of the three fusion parents' chromosomes (93-108). Thus, there must have been a massive and rapid phase of chromosome elimination following the fusion, particularly involving the oat chromosomes (aided by the pre-fusion irradiation treatment), but also involving chromosomes inherited from $T_{1}$ and $T_{2}$.

Table 4 Chromosome content of a bread wheat/oat somatic hybrid derivative

\begin{tabular}{|c|c|c|c|c|c|c|c|}
\hline $\begin{array}{l}\text { A-genome } \\
\text { chromosome }\end{array}$ & $\begin{array}{l}\text { No. of } \\
\text { chromosome }\end{array}$ & $\begin{array}{l}\text { B-genome } \\
\text { chromosome }\end{array}$ & $\begin{array}{l}\text { No. of } \\
\text { chromosome }\end{array}$ & $\begin{array}{l}\text { D-genome } \\
\text { chromosome }\end{array}$ & $\begin{array}{l}\text { No. of } \\
\text { chromosome }\end{array}$ & $\begin{array}{l}\text { Abnormal } \\
\text { chromosome }\end{array}$ & $\begin{array}{l}\text { No. of } \\
\text { chromosome }\end{array}$ \\
\hline $1 \mathrm{~A}$ & 2 & $1 \mathrm{~B}$ & 2 & $1 \mathrm{D}$ & 2 & & \\
\hline $2 \mathrm{~A}$ & 3 & $2 \mathrm{~B}$ & 2 & $2 \mathrm{D}$ & 1 & & \\
\hline $3 \mathrm{~A}$ & 1 & $3 B$ & 3 & $3 \mathrm{D}$ & 1 & & \\
\hline $4 \mathrm{~A}$ & 3 & $4 B$ & 1 & $4 \mathrm{D}$ & 2 & & \\
\hline $5 \mathrm{~A}$ & 4 & $5 B$ & 1 & $5 \mathrm{D}$ & 2 & & \\
\hline $6 \mathrm{~A}$ & 2 & $6 \mathrm{~B}$ & 1 & $6 \mathrm{D}$ & 3 & & \\
\hline \multirow[t]{3}{*}{$7 \mathrm{~A}$} & 2 & $7 \mathrm{~B}$ & 3 & $7 \mathrm{D}$ & 1 & & \\
\hline & & $\mathrm{XB}$ & 1 & & & $X$ & 2 \\
\hline & & YB & 1 & & & $\mathrm{Y}$ & 1 \\
\hline Total & 17 & Total & 15 & Total & 12 & Total & 3 \\
\hline
\end{tabular}

$X B$ and $Y B$ unidentified likely B genome chromosome, based on its FISH profile

$X, Y$, unidentified chromosome

Fig. 4 Sequential FISH and GISH preparations of metaphase chromosomes of a bread wheat/oat somatic hybrid derivative. FISH profiling to identify B (a) and D (b) genome chromosomes. c GISH profile to identify chromosome segments introgressed from oat. Scale bars $10 \mu \mathrm{m}$
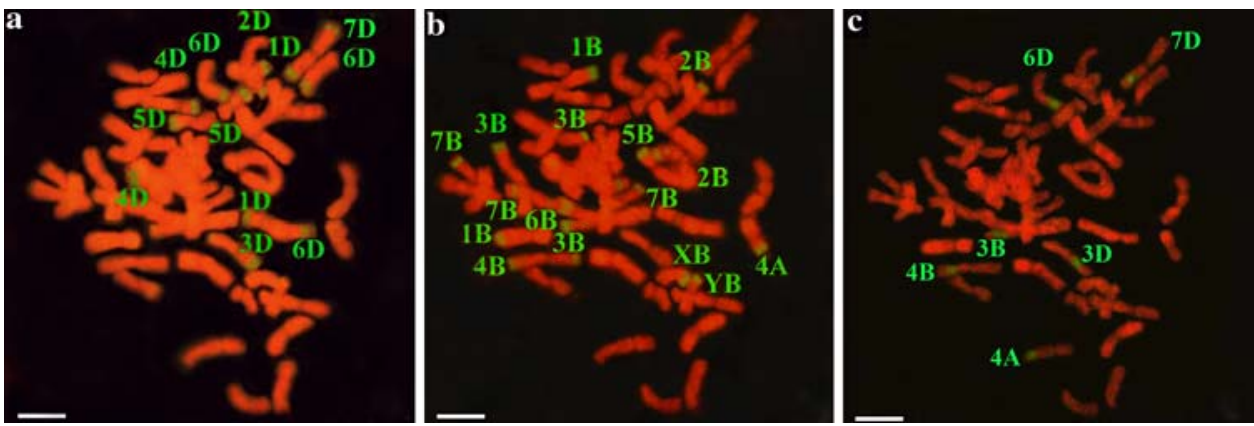
Table 5 Localization of introgressed oat chromatin in a wheat/oat somatic hybrid derivative

$L$ chromosome long arm;

$S$ chromosome short arm

a The distance from the centromere to the break point/ the length of the arm involved $\times 100 \%$

\begin{tabular}{lllll}
\hline Chromosome & & $\begin{array}{l}\text { Cell } \\
\text { number }\end{array}$ & $\begin{array}{l}\text { Relative distance (\%) } \\
\text { from centromere to } \\
\text { the breaking point }\end{array}$ & Arm ratio \\
\hline 4A & L & 27 & $60.55 \pm 11.12$ & $1.45 \pm 0.09$ \\
3B & S & 32 & $21.63 \pm 10.19$ & $1.50 \pm 0.13$ \\
4B & L & 33 & $29.71 \pm 11.25$ & $1.02 \pm 0.07$ \\
3D & S & 38 & $40.57 \pm 12.33$ & $1.46 \pm 0.12$ \\
6D & L & 31 & $58.58 \pm 11.02$ & $1.41 \pm 0.13$ \\
7D & L & 40 & $27.29 \pm 11.57$ & $1.08 \pm 0.08$ \\
\hline
\end{tabular}

Table 6 SSR position on the wheat chromosome of hybrid and the amplification marker

$P$ both parental alleles; $O$ oat allele; $N$ novel allele; $T$ wheat allele

a The distance from the centromere to SSR locus checked/the length of the arm involved $\times 100 \%$

\begin{tabular}{|c|c|c|c|c|c|c|c|}
\hline Primer & Location & $\begin{array}{l}\text { Band } \\
\text { pattern }\end{array}$ & $\begin{array}{l}\text { Relative distance } \\
(\%) \text { from the } \\
\text { centromere }\end{array}$ & Primer & Location & $\begin{array}{l}\text { Band } \\
\text { pattern }\end{array}$ & $\begin{array}{l}\text { Relative distance } \\
(\%) \text { from the } \\
\text { centromere }^{\mathrm{a}}\end{array}$ \\
\hline Xgwm369 & $3 \mathrm{AS}$ & P. $\mathrm{N}$ & 76.36 & Xpsp3030 & 3BS & $\mathrm{O}$ & 21.21 \\
\hline Xgwm674 & $3 \mathrm{AL}$ & $\mathrm{P}$ & 3.33 & Xgwm165 & $4 \mathrm{BL}$ & $\mathrm{P}$ & 19.50 \\
\hline Xwmc258 & $4 \mathrm{AL}$ & $\mathrm{O}$ & 56.00 & Xgwm107 & $4 \mathrm{BL}$ & $\mathrm{P}$ & 3.54 \\
\hline Xwmc262 & $4 \mathrm{AL}$ & $\mathrm{P}$ & 59.33 & Xgwm456 & 3DS & $\mathrm{P}$ & 38.1 \\
\hline Xgwm494 & $6 \mathrm{AL}$ & $\mathrm{P}$ & 3.10 & Xgdm98 & $6 \mathrm{DL}$ & $\mathrm{P}$ & 67.05 \\
\hline Xgwm63 & 7AL & $\mathrm{P}$ & 68.97 & Xpsp3079 & $7 \mathrm{DL}$ & $\mathrm{P}$ & 29.31 \\
\hline Xwmc231 & 3BS & $\mathrm{P}$ & 11.95 & Xgwm428 & 7DL & P. $\mathrm{N}$ & 22.24 \\
\hline
\end{tabular}

Genetic complementation of $\mathrm{T}_{1}, \mathrm{~T}_{2}$ and A. sativa with hybrid plant regeneration

When bread wheat is pollinated by either Hordeum bulbosum or maize, the pollen parent's chromosomes are eliminated during the first few mitotic divisions of the hybrid zygote, a process which has been exploited for the production of dihaploids (Inagaki and Tahir 1990; Chen et al. 1999). Even in compatible wide crosses, which occur in nature and are maintained by polyploidization, a spectrum of genetic and cytological events leads to various modifications (Kashkush et al. 2003; Birchler et al. 2005; James and Reiner 2007; Ma and Gustafson 2008). Thus, it is unsurprising that such events also affect the somatic hybridization process. The $\mathrm{T}_{1}$ cell line has lost the capacity to regenerate, while $\mathrm{T}_{2}$ cells remain totipotent (Xiang et al. 2003a, 2004; Xu et al. 2003). $\mathrm{T}_{2}$ protoplasts cannot divide in vitro, while $\mathrm{T}_{1}$ cells readily form non-regenerable calli. In combination, these two lines are able to contribute both the ability to grow in vitro and totipotency. Thus, it is plausible to suggest that the loss of totipotency of the $T_{1}$ cell line is due to the absence of a critical chromosome(s) and that this absence can be complemented in the fusion nucleus by the contribution of the $\mathrm{T}_{2}$ line genome, where the critical chromosome(s) is still represented. A similar argument can be made for the ability to divide in in vitro culture. In addition, GISH/FISH pattern indicated the introgression of oat chromatin to the 4AL, 3BS, 4BL, 3DS, 6DL and 7DL of the hybrid wheat (Table 5,

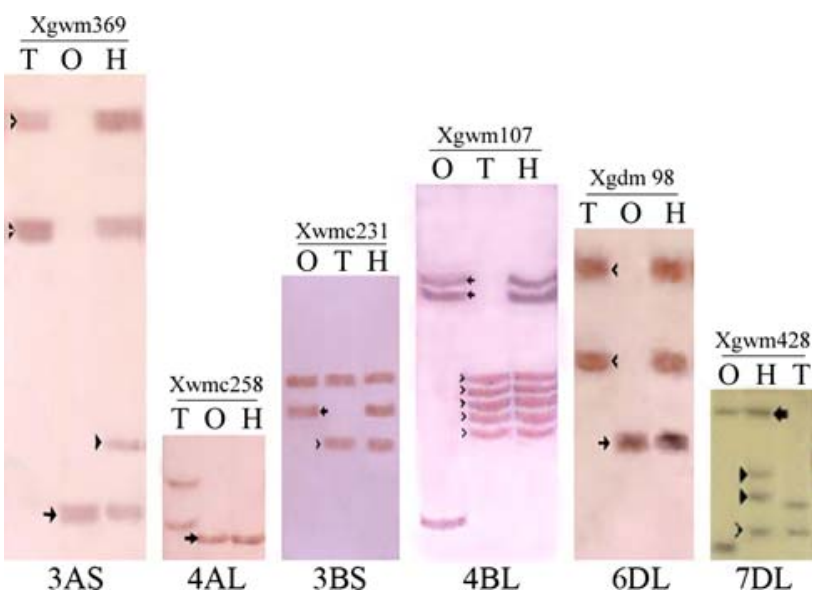

Fig. 5 SSR profiles of cv. Jinan 177 (lane T), oat (lane O) and a bread wheat/oat somatic hybrid derivative (lane $H$ ), based on primers directed to loci on wheat chromosome arms 3AS, 4AL, 3BS, 4BL, 6DL and 7DL. Oat alleles indicated by an arrow, wheat alleles by a thin arrowhead, novel alleles by a full arrowhead

Fig. 4). It is interesting that 10 SSR loci near to the introgression position showed the same profile between the hybrid and oat (Table 6). Therefore, we suggested that hybrid plant regenerated through genetic complementation of $\mathrm{T}_{1}$ and $\mathrm{T}_{2}$ and oat. Somatic hybrid derivatives have also been recovered from other combinations with wheat, including oat, foxtail millet and maize (Xiang et al. 2003a, 2004; Xu et al. 2003), which may be explained by the genetic 
complementation between the $\mathrm{T}_{1}$ and $\mathrm{T}_{2}$ cell lines and the donor species. But no hybrid progenies were produced in these plants from the "Triple parents" (Xiang et al. 2003a, 2004; Xu et al. 2003). In our early reports, hybrid cells from high capacity for regeneration suspension of wheat cv. Jinan 177 with wheatgrass DNA were fertile and heredity stable (Wang et al. 2005). Thus, we suggest that besides the genetic complementation, some other factors also affect the fertileness and genetic stability of these distant hybrid plants. This is worthy of further research (Fig. 5).

Acknowledgments This work was supported by the National Key Technology R\&D Program (2007BAD59B06 to G. X.), the Chinese Ministry of Education New Century Training Program Foundation for Talents (NCET-05-0581 to F. X.) and the Shandong Scientific Committee Excellent Youth Foundation (JQ200810 to F. X.). We are grateful to Dr. Zhang Xueyong (Chinese Academy of Agriculture Sciences) for providing FISH probes pSc119.2 and pAs1.

Open Access This article is distributed under the terms of the Creative Commons Attribution Noncommercial License which permits any noncommercial use, distribution, and reproduction in any medium, provided the original author(s) and source are credited.

\section{References}

Birchler JA, Riddle NC, Auger DL, Veitia RA (2005) Dosage balance in gene regulation: biological implications. Trends Genet 21:219-226

Chen CX, Sun JS, Zhu LH (1999) RFLP variations of common wheat doubled haploid progenies from wheat $\times$ maize crosses. Acta Bot Sin 41:55-59

Doğramaci-Altuntepe M, Peterson TS, Jauhar PP (2001) Anther culture-derived regenerants of durum wheat and their cytological characterization. J Hered 92:56-64

Doyle JJ, Doyle JL (1990) Isolation of plant DNA from fresh tissue. Focus 12:13-15

Gill BS (1987) Chromosome banding methods standard chromosome nomenclature and applications in cytogenetic analysis. In: Heyne EG (ed) Wheat and wheat improvement, 2nd edn. American Society of Agronomy, Madison, pp 243-254

Inagaki M, Tahir M (1990) Comparison of haploid production frequency in wheat varieties crossed with Hordeum bulbosum L. and maize. Jpn J Breed 40:209-216

James AB, Reiner AV (2007) The gene balance hypothesis: from classical genetics to modern genomics. Plant Cell 19:395-402

Jiang J, Chen P, Fribe B, Raupp WJ, Gill BS (1993) Alloplasmic wheat-Elymus ciliaris chromosome addition lines. Genome 37:327-333

Kashkush K, Feldman M, Levy AA (2003) Transcriptional activation of retrotransposons alters the expression of adjacent genes in wheat. Nat Genet 33:102-106

Larkin PJ, Ryan SA, Brettel RIS, Scowcroft WR (1984) Heritable somaclonal variation in wheat. Theor Appl Genet 67:443-455

Lee M, Phillips RL (1988) The chromosomal basis of somaclonal variation. Annu Rev Plant Physiol Plant Mol Biol 39:413-437

Li LL, Xia GM, Chen HM (2001) Asymmetric hybridization between wheat and Millet. Acta Phytophysiol Sin 27:455-460
Liu JH, Xu XY, Deng XX (2005) Intergeneric somatic hybridization and its application to crop genetic improvement. Plant Cell Tissue Organ Cult 82:19-44

Ma XF, Gustafson JP (2008) Allopolyploidization-accommodated genomic sequence changes in triticale. Ann Bot 101:825-832

Malysheva L, Sjakste T, Matzk F, Röder M, Ganal M (2003) Molecular cytogenetic analysis of wheat-barley hybrids using genomic in situ hybridization and barley microsatellite markers. Genome 46:314-322

Mukai Y, Nakahara Y, Yamamoto M (1993) Simultaneous discrimination of the three genomes in hexaploid wheat by multicolor fluorescence in situ hybridization using total genomic and highly repeated DNA probes. Genome 36:489-494

Nagy ED, Molnár-Láng M, Linc G, Láng L (2002) Identification of wheat-barley translocations by sequential GISH and two colour FISH in combination with the use of genetically mapped barley SSR markers. Genome 45:1238-1247

Pershina LA, Dobrovol'skaia OB, Rakovtseva TS, Kravtsova LA, Shchapova AI, Shumny̌ VK (2003) The effect of rye chromosomes on callus induction and regeneration in callus cultures of immature embryos of wheat-rye substitution lines, Triticum aestivum L. cultivar Saratovskaia 29/Secale cereale L. cultivar Onokhoiskaia. Genetika 39:1073-1080

Polanco C, Ruiz ML (2002) AFLP analysis of somaclonal variation in Arabidopsis thaliana regenerated plants. Plant Sci 162:817-824

Röder MS, Korzun V, Wendehake K (1998) A microsatellite map of wheat. Genetics 149:2007-2023

Sears ER (1969) Wheat cytologenetics. Annu Rev Genet 3:451-468

Shaked H, Kashkush K, Ozkan H, Feldman M, Levy AA (2001) Sequence elimination and cytosine methylation are rapid and reproducible responses of the genome to wide hybridization and allopolyploidy in wheat. Plant Cell 13:1749-1759

Silkova OG, Dobrovol'skaia OB, Dubovets NI, Adonina IG, Kravtsova LA, Roeder MS, Salina EA, Shchapova AI, Shumny VK (2006) Production of wheat-rye substitution lines and identification of chromosome composition of karyotypes using Cbanding, GISH, and SSR markers. Genetika 42:793-802

Song XQ, Xia GM, Chen HM (2000) Chromosomal variation in longterm cultures of several related plants in Triticinae. Acta Phytophysiol Sin 26:33-38

Wang J, Xiang FN, Xia GM, Chen HM (2004) Transfer of small chromosome fragments of Agropyron elongatum to wheat chromosome via asymmetric somatic hybridization. Sci Chin Ser C 47:434-441

Wang J, Xiang FN, Xia GM (2005) Agropyron elongatum chromatin localization on the wheat chromosomes in an introgression line. Planta 221:277-286

Xia GM, Chen HM (1996) Plant regeneration from intergeneric somatic hybridization between Triticum aestivum and Leymus chinensis. Plant Sci 120:197-203

Xia GM, Wang H, Chen HM (1996) Plant regeneration from intergeneric asymmetric hybridization between wheat (Triticum aestivum L.) and Russian wildrye (Psathyrostachys juncea (Fisch.) Nevski) and wheat grass (Agropyron elongatum (Host) Nevski). Chin Sci Bull 41:1382-1386

Xia GM, Xiang FN, Zhou AF, Wang H, Chen HM (2003) Asymmetric somatic hybridization between wheat (Triticum aestivum L.) and Agropyron elongatum (Host) Nevishi. Theor Appl Genet 107:299-305

Xiang FN, Xia GM, Zhou AF, Chen HM (1999) Asymmetric somatic hybridization between wheat (Triticum aestivum) and Bromus inermis. Acta Bot Sin 41:458-462

Xiang FN, Xia GM, Chen HM (2003a) Asymmetric somatic hybridization between wheat (Triticum aestivum) and Avena sativa L. Sci Chin Ser C 49:243-252 
Xiang FN, Xia GM, Chen HM (2003b) Effect of UV dosage on somatic hybridization between common wheat (Triticum aestivum L.) and Avena sativa L. Plant Sci 164:697-707

Xiang FN, Xia GM, Zhi DY, Wang J, Nie H, Chen HM (2004) Regeneration of somatic hybrids in relation to the nuclear and cytoplasmic genomes of wheat and Setaria italica. Genome 47:680-688

Xu CH, Xia GM, Zhi DY, Xiang FN, Chen HM (2003) Integration of maize nuclear and mitochondrial DNA into the wheat genome through somatic hybridization. Plant Sci 165:1001-1008
Yue W, Xia GM, Zhi DY, Chen HM (2001) Transfer of salt tolerance from Aeleuropus littoralis sinensis to wheat (Triticum aestivum L.) via asymmetric somatic hybridization. Plant Sci 161:259-266

Zhou AF, Xia GM (2005) Introgression of the Haynaldia villosa genome into $\gamma$-ray-induced asymmetric somatic hybrids of wheat. Plant Cell Rep 24:289-296 